\title{
Pengaruh Dimensi Tiang Mini Dan Faktor Aman Terhadap Lendutan Pelat Terpaku Tiang Tunggal
}

\author{
The Effect of Mini Pile Dimensions And Safe Factors on The Deflection of Single-Pile Nailed \\ Slab
}

\author{
Ferly Oktavia ${ }^{1}$, Anas Puri ${ }^{2}$ dan Roza Mildawati ${ }^{2}$ \\ ${ }^{1}$ Mahasiswa Program Studi Teknik Sipil, Universitas Islam Riau, Pekanbaru \\ ferlyoktavia@student.uir.ac.id \\ ${ }^{2}$ Pengajar Program Studi Teknik Sipil, Universitas Islam Riau, Pekanbaru \\ anaspuri@eng.uir.ac.id \\ rozamildawati@eng.uir.ac.id
}

\begin{abstract}
Abstrak
Perkerasan Sistem Pelat Terpaku merupakan pengembangan Sistem Cakar Ayam yang berfungsi sebagai salah satu alternatif solusi untuk mengatasi permasalahan konstruksi jalan pada tanah lunak. Selain itu, kenaikan kapasitas dukung tanah dasar akibat pengaruh dukungan tiang-tiang pada pelat akan mengurangi kebutuhan tebal perkerasan beton dan memperkaku sistem perkerasan. Penelitian ini bertujuan untuk mempelajari pengaruh diameter tiang masif dan faktor aman terhadap lendutan pelat terpaku tiang tunggal. Dimensi struktur pelat terpaku dan data material mengacu pada Puri (2017). Sistem ini dibebani dengan pembebanan tekan sentris. Perhitungan lendutan dan gaya dalam pelat menggunakan metode BoEF, berdasarkan tambahan modulus reaksi tanah dasar ekivalen yang dibandingkan dengan lendutan hasil pengamatan. Hasil analisis menunjukkan bahwa besaran faktor aman mempengaruhi nilai lendutan hitungan. Lendutan hitungan meningkat dengan peningkatan faktor aman. Penggunaan faktor aman 1,0 memiliki pola lendutan mendekati lendutan pengamatan untuk tiang bulat. Analisis perhitungan lendutan dengan ukuran mini pile yang semakin besar menghasilkan lendutan pelat yang semakin kecil. Variasi $S F$ tidak berpengaruh signifikan terhadap momen pelat.
\end{abstract}

Kata kunci : diameter pelat, lendutan pelat, pelat-terpaku, reaksi subgrade

\begin{abstract}
The Nailed-Slab Pavement System is the development from the pavement of the Cakar Ayam System which as an alternative solution to solve the problem of road construction in soft soil. In addition, the increase in bearing capacity of the subgrade due to the influence of the poles support on the plate will reduce the need for thick concrete pavement and strengthen the pavement system. This study aims to learn the effect of massive pole diameter and safe factors on the deflection of single-pile Nailed Slab. The dimensions of the Nailed-slab structure and material refer to Puri (2017). This system is burdened with press centric loading. Calculation of deflection and force in plates uses the BoEF method, based on the additional modulus of the subgrade equivalent reaction which is compared to the deflection observed. The results of the analysis show that the magnitude of the safe factor affects the value of the deflection calcutation. This deflection increases with an increase in safe factors. The use of the safe factor 1.0 has a deflection pattern that is closer to the observation deflection for the round pile. Analysis of the deflection calculation with the size of the mini pile which gets bigger results in a smaller slab deflection. SF variations have no significant effect on the plate moment.
\end{abstract}

Keyword: pile diameter, plate deflection, nailed-slab, subgrade reaction,

\section{PENDAHULUAN}

Perkerasan kaku digunakan untuk perkerasan jalan di atas tanah lunak. Jika perkerasan jalan terletak pada tanah dasar berada di atas tanah lunak atau ekspansif, sering mengalami deformasi yang berlebihan oleh beban kendaraan berat, sedangkan menurut Hardiyatmo (2012), metode perancangan perkerasan jalan yang telah ada, umumnya diasumsikan bahwa 
tanah-dasar dalam kondisi stabil, sehingga tebal komponen struktur perkerasan hanya didasarkan pada daya dukung tanah-dasar yang dinyatakan oleh nilai CBR atau modulus reaksi subgrade vertikal. Perkerasan jalan tidak hanya menerima beban siklik oleh kendaraan, namun juga menerima beban akibat temperatur yang membuat perkerasan jalan mengalami momen lentur bolak-balik (Puri, 2015).

Sistem Pelat Terpaku merupakan salah satu alternatif solusi untuk mengatasi permasalahan konstruksi jalan yang melalui tanah lunak. Menurut Hardiyatmo (2016), Sistem Pelat Terpaku cocok digunakan untuk perkerasan yang tanah dasarnya dipengaruhi oleh penurunan tidak seragam, karena interaksi tanah-tiang-pelat membuat pelat lebih kaku, sehingga mengurangi terjadinya beda penurunan permukaan perkerasan (menciptakan permukaan perkerasan beton yang selalu rata).

Sistem Pelat Terpaku (Nailed Slab System) yang ditemukan oleh Prof. Dr. Ir. Hary Christady Hardiyatmo, M.Eng.,DEA (2008) adalah suatu perkerasan beton bertulang (tebal antara $12-20 \mathrm{~cm}$ ) yang didukung oleh tiang-tiang mini (panjang $150-200 \mathrm{~cm}$ dan diameter $15-20 \mathrm{~cm}$ ). Tiang-tiang dan pelat beton dihubungkan secara monolit dengan bantuan tulangan-tulangan. Interaksi antara pelat beton-tiang-tanah disekitarnya menciptakan suatu perkerasan yang lebih kaku, yang lebih tahan terhadap deformasi tanah-dasar.

Puri (2017) telah melakukan analisis variasi faktor aman pada modulus reaksi subgrade ekivalen untuk model skala penuh Pelat Terpaku satu baris tiang dengan pembebanan tekan sentris. Sistem tersebut berada pada media tanah lempung lunak. Belum dilakukan analisis penerapan variasi faktor aman tersebut pada Pelat Terpaku tiang tunggal, sehingga dapat diperoleh informasi kemungkinan perbedaan hasil analisis.

Penelitian ini akan menerapkan nilai modulus reaksi subgrade ekivalen ( $\left.k^{\prime}\right)$ dengan pendekatan variasi faktor aman pada nilai tambahan modulus reaksi subgrade $(\Delta k)$ dan beberapa varian ukuran tiang untuk Sistem Pelat Terpaku tiang tunggal. Nilai modulus reaksi subgradeekivalen ( $\left.k^{\prime}\right)$ merupakan hasil penambahan nilai modulus reaksi subgrade $(k)$ dan tambahan modulus reaksi subgrade $(\Delta k)$ akibat adanya tiang, nilai ini digunakan dalam perencanaan Sistem Pelat Terpaku. Tambahan nilai modulus tanah dasar di bawah pelat karena instalasi tiang dinyatakan sebagai kontribusi perlawanan tiang (Puri, dkk, 2012).

\section{MODULUS REAKSI SUBGRADE EKIVALEN $\left(K^{\prime}\right)$}

Modulus reaksi subgrade ekivalen adalah modulus reaksi akibat adanya tiang-tiang beserta pelat. Nilai modulus reaksi subgrade ekivalen $\left(k^{\prime}\right)$ diperoleh dengan menjumlahkan nilai modulus reaksi subgrade tanah $(k)$ dan nilai tambahan dari modulus reaksi dari tiang tunggal $(\Delta k)$. Hardiyatmo (2011) mengusulkan metode penentuan tambahan modulus $\Delta k$. Puri, dkk, (2012b) menyederhanakan metode yang diusulkan oleh Hardiyatmo tersebut dengan mempertimbangkan penurunan izin dari perkerasan.

Koefisien reaksi subgrade adalah hubungan konseptual antara tekanan tanah dengan defleksi (Bowles, 1982 dalam Muhu, 2007). Salah satu besaran yang dapat digunakan dalam analisis lendutan pelat adalah koefisien reaksi tanah dasar.

Pada sistem pelat terpaku, pendekatan penentuan modulus reaksi subgrade ekivalen ( $k$ ') didefinisikan sebagai modulus reaksi subgrade yang memperhatikan kontribusi tiang dalam menahan gesekan perpindahan vertikal pelat ditentukan (Hardiyatmo, 2011; Dewi, 2009; Puri, et.al., 2011b, 2012a) sebagai berikut :

$k^{\prime}=k+\Delta k$

Keterangan :

$k^{\prime}=$ modulus reaksi subgrade ekivalen pelat terpaku $\left(\mathrm{kN} / \mathrm{m}^{3}\right)$ 
$k=$ modulus reaksi subgrade dari tanah $\left(\mathrm{kN} / \mathrm{m}^{3}\right)$

$\Delta k=$ tambahan modulus reaksisubgrade karena adanya tiang $\left(\mathrm{kN} / \mathrm{m}^{3}\right)$

\section{Modulus Reaksi Subgrade Ekivalen Metode Hardiyatmo Modifikasi}

Metode Hardiyatmo Modifikasi (Puri, dkk., 2012) merupakan salah satu metode yang digunakan dalam menentukan nilai modulus reaksi subgrade ekivalen, metode ini merupakan modifikasi dari metode Hardiyatmo (2011).

Metode Hardiyatmo (2011) menggunakan pendekatan reduksi tahanan tiang dalam penentuan $\Delta k$. Perpindahan relatif antara tanah dan tiang, dan reduksi tahanan tiang telah diperhitungkan. Untuk keperluan desain praktis, penentuan reduksi tahanan tiang sulit diperhitungkan. Puri, dkk, (2012a) mengusulkan suatu pendekatan dalam penentuan tambahan modulus reaksi subgrade dengan menggunakan penurunan izin/toleransi pelat perkerasan.

Untuk pelat terpaku yang berada diatas tanah lunak, maka tahanan ujung tiang diabaikan. Untuk lempung lunak atau lempung terkonsolidasi normal, factor adhesi didapat sebesar 1,0 (Flemming, dkk, 2009; Wai, dkk, 2006 dalam Puri, dkk, 2012). Faktor adhesi $a_{\mathrm{d}}$ dapat ditentukan berdasarkan kurva Tomlinson pada Grafik McClelland (1974) dengan menggunakan nilai $c_{u}$, dapat dilihat pada Gambar 1 .

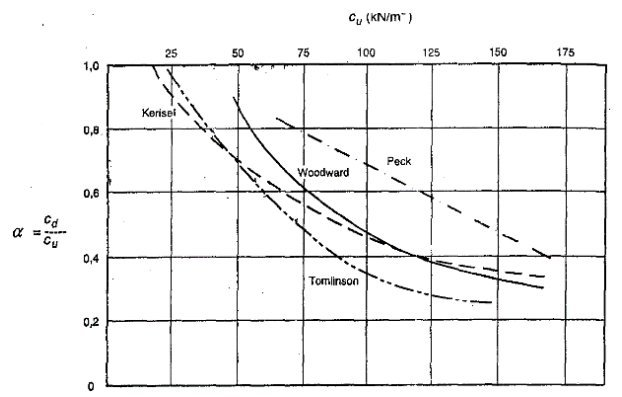

Gambar 1. Faktor adhesi untuk tiang pancang pada tanah lempung Sumber : McClelland (1974)
Menurut Puri, dkk (2012), mobilisasi perlawanan gesek tiang masih dalam zona elastis. Menurut aturan praktis dalam menentukan kapasitas dukung tiang diizinkan biasanya diambil pada $1 / 2,5$ kapasitas ultimit. Dimana 2,5 adalah factor aman $(S F)$. Dengan mengambil $\alpha=1 / \mathrm{SF}=$ $1 / 2,5$ dengan asumsi perpindahan kepala tiang sama dengan penurunan toleransi perkerasan pelat kaku $\left(\delta_{p}=\delta_{a}\right.$; maka $\beta=1$ $\left(\delta_{a}\right)$. Oleh karena itu, tambahan modulus reaksi subgrade karena adanya tiang dibawah pelat dimodifikasi dengan (Puri, dkk. 2012):

$\Delta k=\frac{f_{s} A_{s}}{2,5 \delta_{a} A_{p s}}$

Dan persamaan (2) tersebut ditulis (Puri, 2015) menjadi:

$\Delta k=\frac{f_{s} A_{s}}{S F \delta_{a} A_{p s}}$

Sehingga modulus reaksi subgrade ekivalen dapat dihitung dengan :

$k^{\prime}=k+\frac{f_{s} A_{s}}{S F \delta_{a} A_{p s}}$

Keterangan :

$f_{s}=$ tahanan gesek satuan tiang $\left(\mathrm{kN} / \mathrm{m}^{2}\right)$ $f_{s}=a_{\mathrm{d}} \cdot c_{u}$,

$a_{\mathrm{d}}=$ faktor adhesi,

$c=$ kohesi $\left(\mathrm{kN} / \mathrm{m}^{2}\right)$,

$\delta_{a}=$ toleransi penurunan pelat perkerasan kaku sebesar $5(\mathrm{~mm})$,

$A_{s}=$ luas selimut tiang $\left(\mathrm{m}^{2}\right)$,

$A_{\mathrm{ps}}=$ luasan zona pelat yang didukung oleh satu tiang $\left(\mathrm{m}^{2}\right), A_{\mathrm{ps}}=s^{2}$,

$s \quad=$ jarak antar tiang $(\mathrm{m})$,

$2,5=$ konstanta faktor aman $(S F)$.

\section{METODOLOGI PENELITIAN}

Penelitian dilakukan di Prodi Teknik Sipil Unversitas Islam Riau dan Laboratorium Komputasi FT Universitas Islam Riau.

Tahapan penelitian dimulai dengan pengumpulan data sekunder yaitu hasil uji skala penuh Sistem Pelat Terpaku pada lempung lunak (Puri, 2017) untuk Pelat Terpaku Tiang Tunggal seperti pada 
Gambar 2 dengan sifat-sifat tanah dan beton seperti ditunjukkan pada Tabel 1, kemudian perhitungan modulus reaksi subgrade ekivalen ( $\left.k^{\prime}\right)$ menggunakan Metode Hardiyatmo Modifikasi dengan variasi faktor aman. Selanjutnya, perhitungan berdasarkan lendutan pengamatan (Puri,
2017) sebagai lendutan izin $\left(\delta_{\mathrm{a}}=\delta_{\mathrm{s}}\right)$ dan lendutan izin maksimum $\left(\delta_{\mathrm{a}}=5 \mathrm{~mm}\right)$. Khusus untuk lendutan izin maksimum dilakukan pula variasi dimensi tiang mini berpenampang bujur sangkar dengan variasi (dalam cm) $20 \times 20,25 \times 25,28 \times 28$, dan $32 \times 32$.

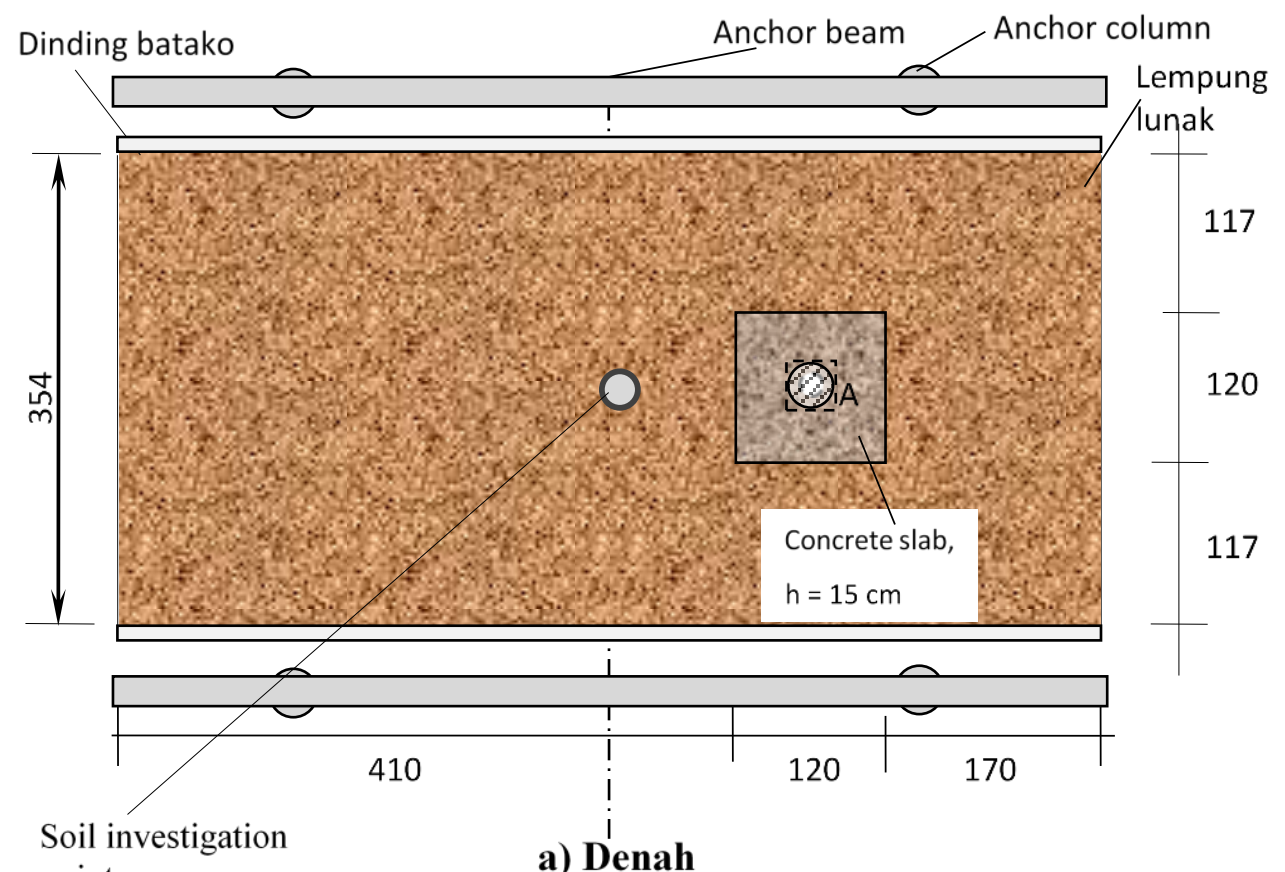
point

a) Denah

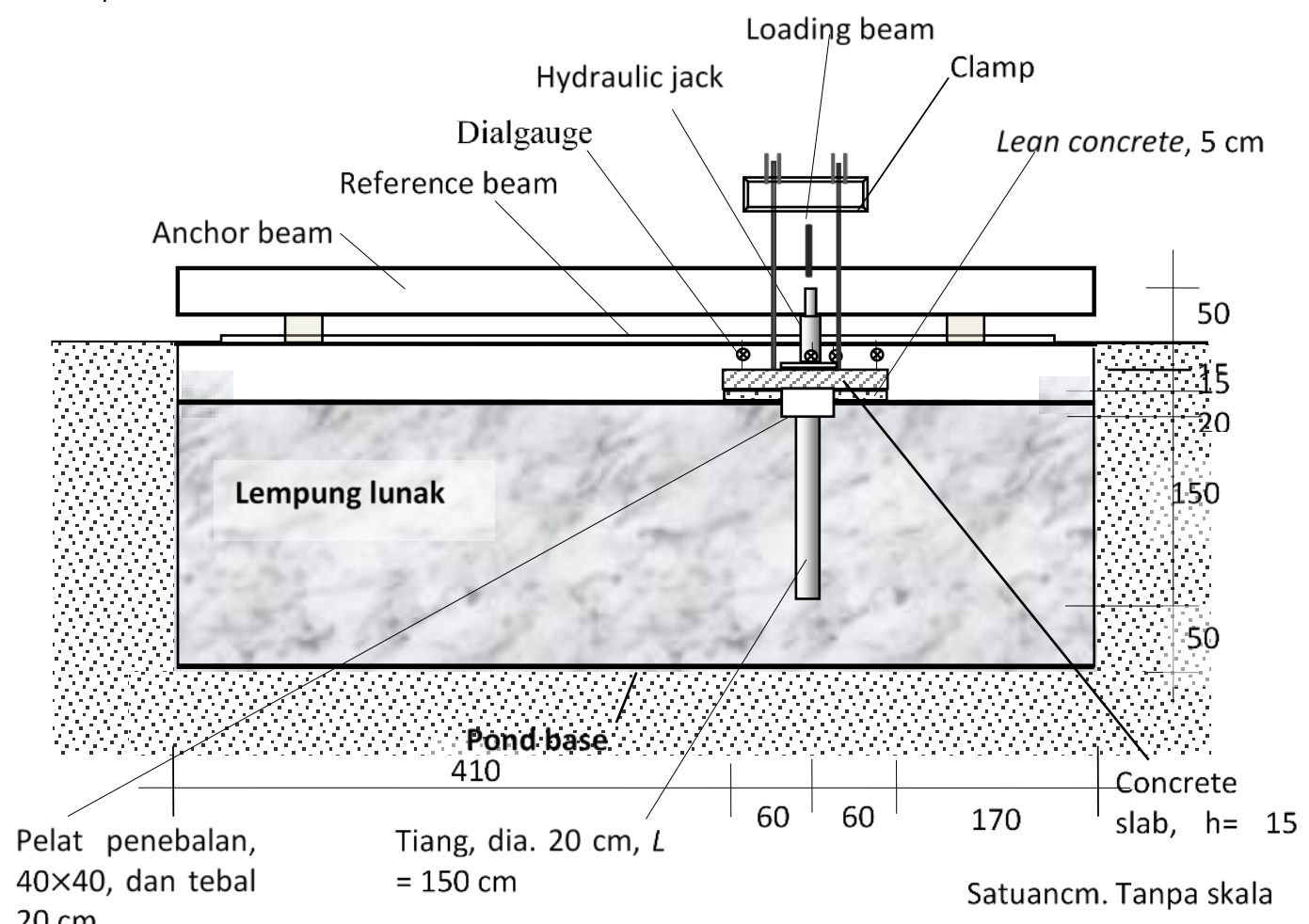

b) Potongan memanjang dan alat uji

Gambar 2. Perkerasan Sistem Pelat Terpaku Tiang Tunggal (Puri, 2017) 
Tabel 1. Sifat-sifat Lempung dan Beton

\begin{tabular}{|c|c|c|c|}
\hline No. & Parameter & Unit & Rerata \\
\hline \multicolumn{4}{|c|}{ A. Lempung Lunak } \\
\hline 1. & $\begin{array}{l}\text { Berat Spesifikasi, } \\
G_{s}\end{array}$ & - & 2,55 \\
\hline 2. & $\begin{array}{l}\text { Batas-batas } \\
\text { Konsistensi : } \\
\text { - Batas Cair, } L L \\
\text { - Batas Plastis, } P L \\
\text { - Batas Susut, } S L \\
\text { - Indeks Plastisitas, } \\
\quad P I \\
\text { - Indeks Cair, } L I\end{array}$ & $\begin{array}{l}\% \\
\% \\
\% \\
\% \\
\%\end{array}$ & $\begin{array}{c}88,46 \\
28,48 \\
9,34 \\
59,98 \\
0,36\end{array}$ \\
\hline 3. & Kadar Air, $w$ & $\%$ & 54,87 \\
\hline 4. & Kadar Lempung & $\%$ & 92,93 \\
\hline 5. & Kandungan Pasir & $\%$ & 6,89 \\
\hline 6. & $\begin{array}{l}\text { Berat Volume } \\
\text { Basah, } \gamma\end{array}$ & $\mathrm{kN} / \mathrm{m}^{3}$ & 16,32 \\
\hline 7. & $\begin{array}{l}\text { Berat Volume } \\
\text { Kering, } \gamma_{\mathrm{d}}\end{array}$ & $\mathrm{kN} / \mathrm{m}^{3}$ & 10,90 \\
\hline 8. & $\begin{array}{l}\text { Kuat Geser } \\
\text { Undrained, } S_{u} \\
\text { - Tak Terganggu } \\
\text { - Remolded } \\
\end{array}$ & $\begin{array}{l}\mathrm{kN} / \mathrm{m}^{2} \\
\mathrm{kN} / \mathrm{m}^{2}\end{array}$ & $\begin{array}{l}20,14 \\
11,74\end{array}$ \\
\hline 9. & CBR & $\%$ & 0,83 \\
\hline 10. & $\begin{array}{l}\text { Klasifikasi Tanah : } \\
\text { - AASHTO } \\
\text { - USCS }\end{array}$ & $\begin{array}{l}- \\
-\end{array}$ & $\begin{array}{c}\text { A-7-6 } \\
\mathrm{CH}\end{array}$ \\
\hline \multicolumn{4}{|c|}{ B. Beton } \\
\hline 11. & $\begin{array}{l}\text { Pelat } \\
\text { bertulang: } \\
\text { - Kuat tekan } \\
\text { - Kuat tarik }\end{array}$ & $\begin{array}{c}\mathrm{MPa} \\
\mathrm{kPa}\end{array}$ & $\begin{array}{c}29,21 \\
3,13\end{array}$ \\
\hline 12. & $\begin{array}{l}\text { Kuat tekan beton } \\
\text { tiang }\end{array}$ & $\mathrm{MPa}$ & 17,4 \\
\hline 13. & $\begin{array}{lll}\text { Kuat tekan lantai } \\
\text { kerja }\end{array}$ & $\mathrm{MPa}$ & 14,5 \\
\hline
\end{tabular}

Sumber : Puri (2017)

Analisis dilakukan semi-manual yang didasari pada perkerasan Pelat Terpaku tiang tunggal, perhitungan nilai modulus reaksi subgrade ekivalen ( $\left.k^{\prime}\right)$ dengan tambahan modulus reaksi subgrade $(\Delta k)$ Metode Hardiyatmo Modifikasi sebagaimana Persamaan (1) dan (3), dan perhitungan lendutan dan gaya dalam dilakukan dengan bantuan program "BoEF.xls" Program Versi 1.4 .

Lebih jelasnya tahapan-tahapan penelitian dirangkum ke dalam sebuah bagan alir sebagaimana Gambar 3 .

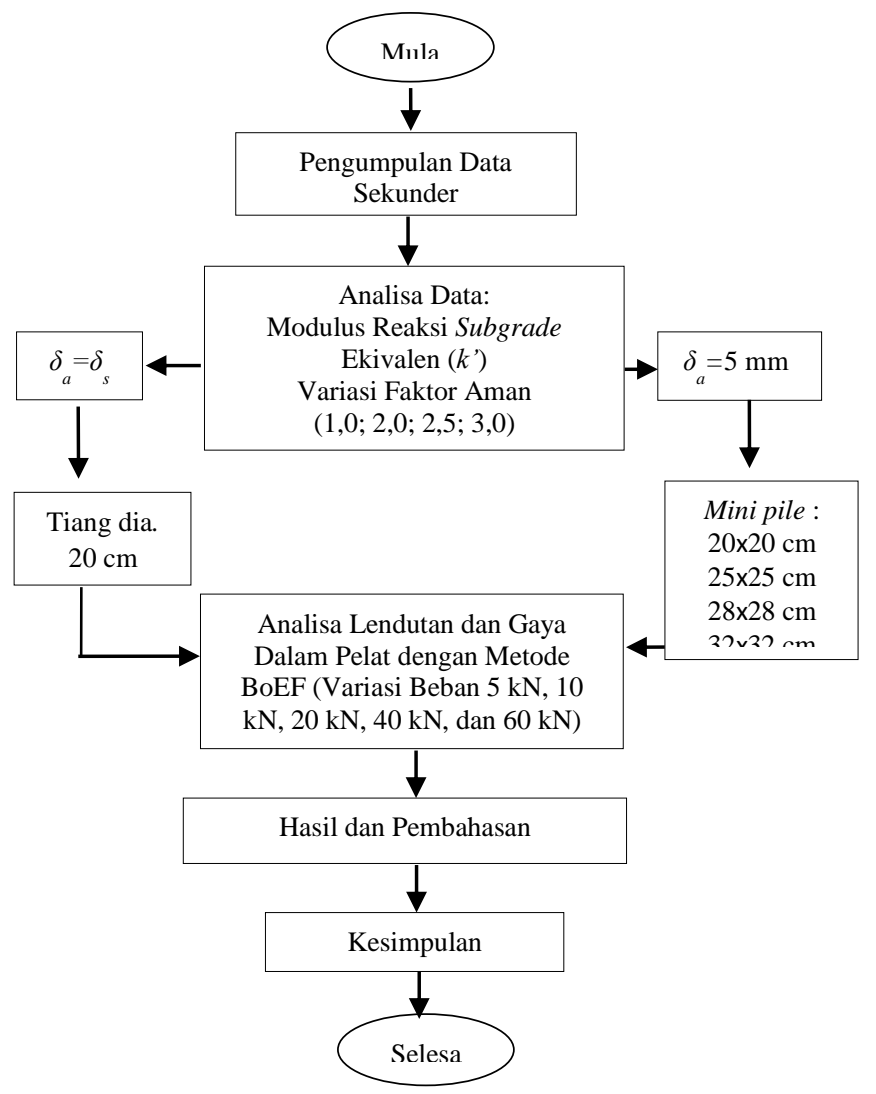

Gambar 3. Bagan Alir Penelitian

\section{HASIL DAN PEMBAHASAN}

Beban yang digunakan sebesar $5 \mathrm{kN}, 10 \mathrm{kN}$, $20 \mathrm{kN}, 40 \mathrm{kN}$ dan $60 \mathrm{kN}$, sesuai dengan beban yang ditinjau pada penelitian terdahulu (Puri, 2017). Hubungan beban dan lendutan pelat diberikan pada Gambar 4. Perhitungan berdasarkan lendutan pengamatan sebagai lendutan izin $\left(\delta_{a}=\delta_{s}\right)$ ditinjau pada pembebanan tengah pelat.

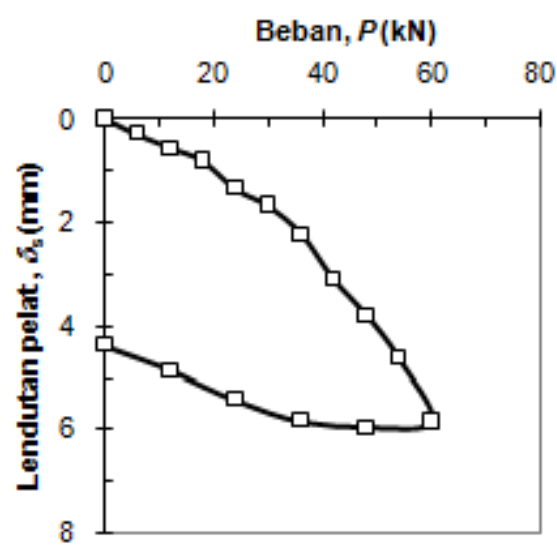

Gambar 4. Hubungan $P-\delta$ Pelat Terpaku tiang tunggal

Sumber : Puri (2017) 
Penyederhanaan hitungan untuk BoEF dilakukan sebagai berikut: (a) lantai kerja diabaikan, guna desain pada zona lebih aman, (b) pelat penebalan/pelat konektor juga diabaikan. Perhitungan $\Delta k$ dengan 2 cara perhitungan yaitu menggunakan lendutan pengamatan sebagai lendutan izin $\left(\delta_{a}=\delta_{s}\right)$ dan lendutan izin maksimum $\left(\delta_{a}=5\right.$ $\mathrm{mm})$. Besaran untuk perhitungan modulus $k$ ' dan $\Delta k$ (lihat Appendiks). Berdasarkan data dan besaran tersebut dilakukan perhitungan nilai $\Delta k$ menggunakan Persamaan (3), kemudian perhitungan nilai $k^{\prime}$ dengan Persamaan (1) (hasil perhitungan lihat Appendiks).

\section{Lendutan dan Gaya Dalam Pelat Terpaku Tiang Tunggal Diameter $20 \mathrm{~cm}$}

\section{1) Berdasarkan Lendutan Pengamatan sebagai Lendutan Izin $\left(\delta_{a}=\delta_{s}\right)$}

Perhitungan berdasarkan lendutan pengamatan sebagai lendutan izin $\left(\delta_{a}=\delta_{s}\right)$ ditinjau pada pembebanan tengah pelat pada Pelat Terpaku tiang tunggal diameter $20 \mathrm{~cm}$. Hasil hitungan lendutan di titik beban diberikan pada Gambar 5. Terlihat bahwa pola lendutan hitungan sudah bersesuaian dengan pengamatan. Variasi SF mempengaruhi besaran lendutan hitungan dimana lendutan hitungan cenderung lebih besar dibanding pengamatan. Namun, semakin besar $S F$ maka semakin besar perbedaan lendutan hitungan. Hal tersebut bersesuai dengan Puri (2017) untuk Pelat Terpaku dengan satu baris tiang pada lempung lunak. Hal serupa bahwa semakin besar $S F$ maka perbedaan lendutan hitungan semakin signifikan. Lendutan pelat pada beban roda tunggal $40 \mathrm{kN}$ cenderung di bawah lendutan izin maksimum 5,0 mm.

Gambar 6 memperlihatkan hubungan momen lentur pelat dan beban. Peningkatan beban meningkatkan momen pelat. Namun peningkatan $S F$ tidak berpengaruh signifikan terhadap momen.

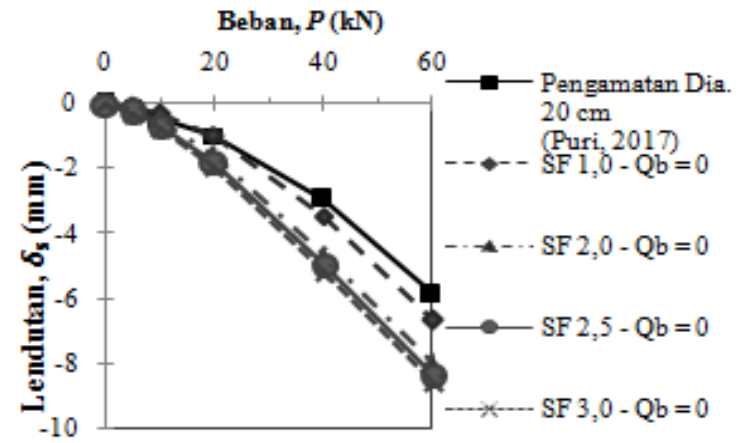

Gambar 5. Hubungan $P-\delta$ dengan berbagai variasi $S F$ untuk tiang diameter $20 \mathrm{~cm}$

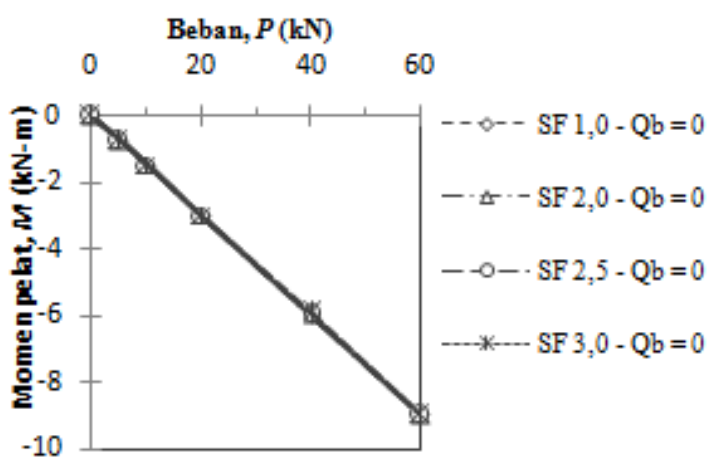

Gambar 6. Hubungan momen dan beban dengan berbagai variasi $S F$ untuk tiang diameter $20 \mathrm{~cm}$

2) Berdasarkan Lendutan Izin Maksimum $\left(\delta_{a}=5 \mathrm{~mm}\right)$

Perhitungan berdasarkan lendutan izin maksimum $\left(\delta_{a}=5 \mathrm{~mm}\right)$ Pelat Terpaku tiang tunggal mini pile $20 \mathrm{~cm}$ x $20 \mathrm{~cm}, 25 \mathrm{~cm}$ x 25 $\mathrm{cm}, 28 \mathrm{~cm} \times 28 \mathrm{~cm}$, dan $32 \mathrm{~cm} \times 32 \mathrm{~cm}$. Hasil hitungan dalam bentuk hubungan $P-\delta$ diberikan pada Gambar 7. Terlihat bahwa untuk semua ukuran penampang tiang menghasilkan lendutan semakin kecil dengan semakin rendahnya $S F$. Lendutan pelat semakin berkurang dengan bertambahnya dimensi penampang tiang. Semakin besar dimensi penampang tiang, lendutan akibat beban roda tunggal $40 \mathrm{kN}$ cenderung berkurang dan lebih rendah dari lendutan izin maksimum 5,0 mm.

Hubungan momen dan beban dengan variasi $S F$ untuk mini pile $32 \mathrm{~cm}$ x $32 \mathrm{~cm}$ diberikan pada Gambar 8. Variasi $S F$ tidak berpengaruh signifikan pada momen. Untuk ukuran penampang tiang lainnya mempunyai hasil yang relatif sama. Variasi 
dimensi penampang tiang mini juga tidak berpengaruh signifikan pada momen.

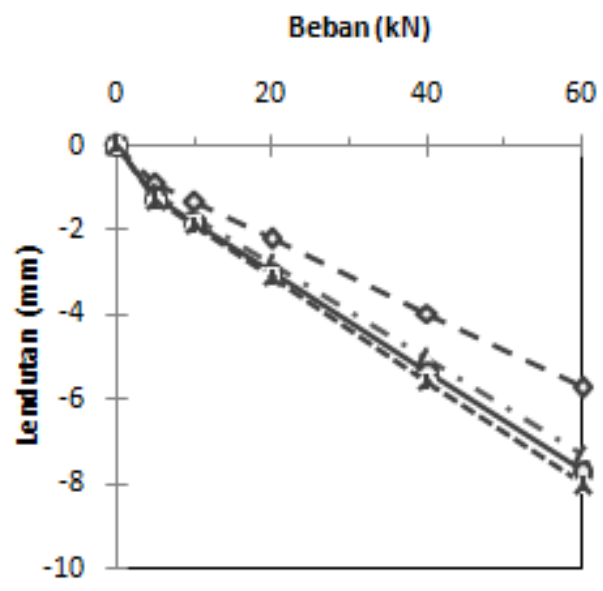

(a) $20 \mathrm{~cm} \times 20 \mathrm{~cm}$

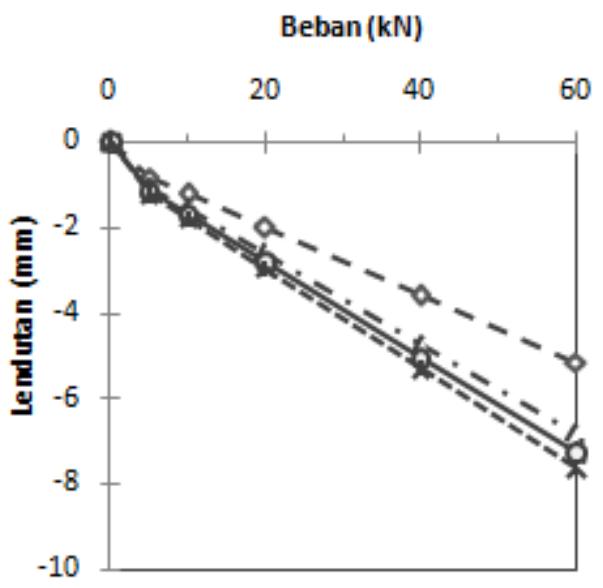

(b) $25 \mathrm{~cm} \mathrm{x} 25 \mathrm{~cm}$

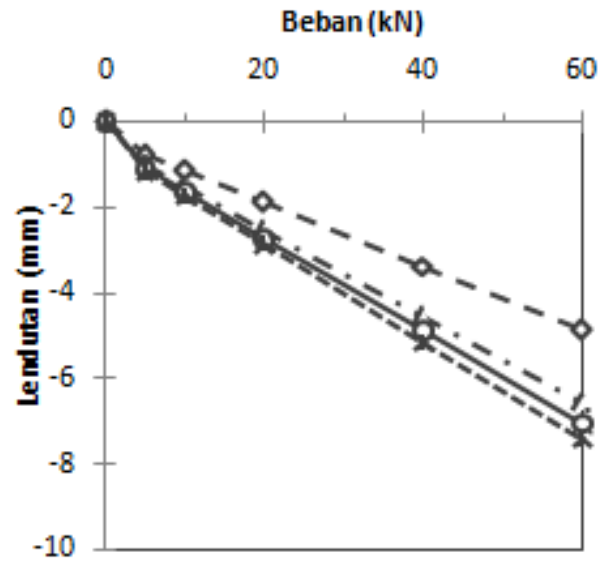

(c) $28 \mathrm{~cm} \mathrm{x} 28 \mathrm{~cm}$

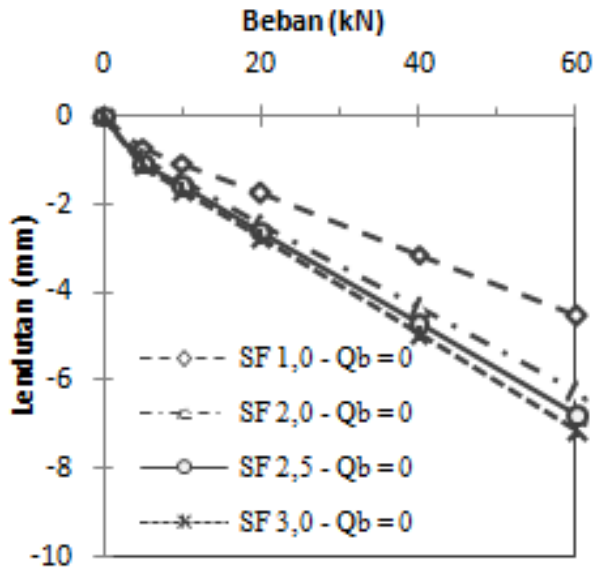

(d) $32 \mathrm{~cm} \times 32 \mathrm{~cm}$

Gambar 7. Hubungan $P-\delta$ dengan berbagai variasi $S F$ dan ukuran mini pile.

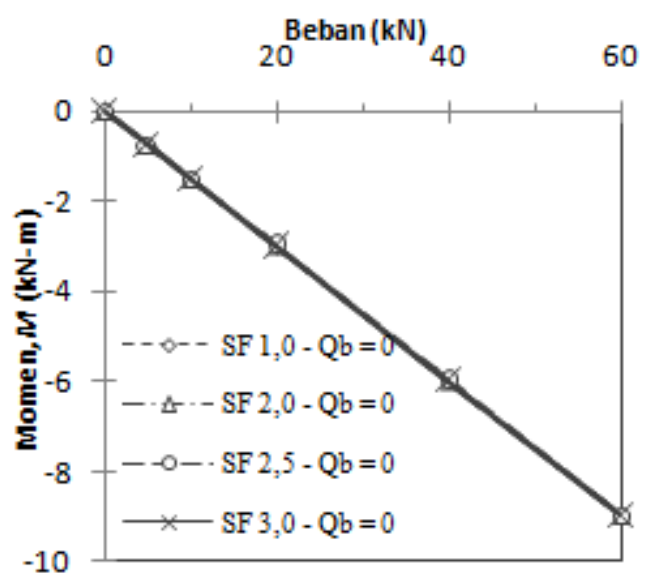

Gambar 8. Hubungan momen dan beban dengan variasi $S F$ untuk mini pile $32 \mathrm{~cm} \mathrm{x}$ $32 \mathrm{~cm}$.

\section{KESIMPULAN DAN SARAN}

Berdasarkan hasil analisis dan pembahasan dapat disimpulkan sebagai berikut :

1. Hasil analisis menunjukkan bahwa besaran faktor aman mempengaruhi nilai lendutan hitungan. Lendutan hitungan meningkat dengan peningkatan faktor aman. Penggunaan faktor aman 1,0 memiliki pola lendutan yang sangat mendekati lendutan pengamatan untuk tiang bulat.

2. Analisis perhitungan lendutan dengan ukuran mini pile yang semakin besar menghasilkan lendutan pelat yang semakin kecil.

3. Variasi $S F$ tidak berpengaruh signifikan terhadap momen pelat.

Dari kesimpulan diketahui lendutan pelat dipengaruhi variasi SF dan ukuran mini pile 
yang digunakan. Oleh sebab itu, selanjutnya dapat dilakukan analisis lendutan dengan variasi ukuran tebal pelat.

\section{UCAPAN TERIMA KASIH}

Naskah ini bagian dari penelitian Penerapan Faktor Aman Modulus Reaksi Subgrade Ekivalen pada Perkerasan Sistem Pelat Terpaku Tiang Tunggal atas dukungan finansial dari Lembaga Penelitian dan Pengabdian Masyarakat (LPPM) Universitas Islam Riau dengan nomor kontrak 367/KONTRAK/LPPM-UIR/4-2018.

\section{DAFTAR PUSTAKA}

Afriliyani, N., Puri, A., Ardiansyah, R. (2017). "Penerapan Modulus Reaksi Subgrade Ekivalen Metode Puri, dkk (2012) dalam Perhitungan Lendutan Pelat pada Perkerasan Sistem Cakar Ayam Modifikasi”. Prosiding Konferensi Nasional Teknik Sipil dan Perencanaan (KN-TSP) 2017, Program Studi Teknik Sipil, Universitas Islam Riau, Pekanbaru, 9 Februari 2017, pp. 29-35.

Agustin, D.R., Puri, A., Ardiansyah, R. (2017). "Perhitungan Lendutan Perkerasan Jalan Sistem Cakar Ayam Modifikasi dengan Variasi Faktor Aman pada Tambahan Modulus Reaksi Subgrade".Prosiding Konferensi Nasional Teknik Sipil dan Perencanaan (KN-TSP) 2017, Program Studi Teknik Sipil, Universitas Islam Riau, Pekanbaru, 9 Februari 2017, pp. 76-84.

Das, B.M. (2011). Principle of Foundation Engineering, 7ed., Stamford: Cencage Learning

Dewi, D.A. (2009). Kajian Pengaruh Tiang Tunggal Terhadap Nilai Koefisien Reaksi Subgrade Ekivalen Pada Uji Beban Skala Penuh, Tesis, Program Studi Teknik Sipil, Program Pascasarjana UGM, Yogyakarta, Indonesia.

Hardiyatmo, H.C. (2008).

'Sistem'PelatTerpaku' (Nailed Slab) Untuk Perkuatan Pelat Beton Pada
Perkerasan Kaku (Rigid Pavement)". Prosiding Seminar Nasional Teknologi Tepat Guna dalam Penanganan Saranaprasarana, MPSP JTSL FT UGM., pp. $\mathrm{M}-1-\mathrm{M}-7$.

Hardiyatmo, H.C. (2009). Metoda Hitungan Pelat dengan Menggunakan Modulus Reaksi Tanah Dasar Ekivalen untuk Struktur Pelat Fleksibel, sub mitted in Dinamika Teknik.

Hardiyatmo, H.C. (2011). "Method to Analyze the Deflection of the NailedSlab System". International Journal of Civil and Environmental Engineering IJCEE-IJENS. Volume 11 Number 4, pp.22-28.

Muhu, H.L.Y. (2007). Kajian Lendutan Pada Sistem Cakar Ayam Akibat Variasi Lebar Pelat (Model Sistem Cakar Ayam dari Pelat Baja). Tugas Akhir, Program Studi Teknik Sipil dan Lingkungan, UGM, Yogyakarta, Indonesia.

Puri, A. (2017). "Developing the Curve of Displacement Factor for Determination The Additional Modulus of Subgrade Reaction on Nailed-slab Pavement System". International Journal of Technology (IJTech), Vol. 8 No. 1 (2017)124-133. ISSN2086-9614. 6 Agustus 2018.

http://ijtech.eng.ui.ac.id/article/view/23 2.

Puri, A. (2017). "Effect Of Safety Factors On The Calculated Deflection Of 1-Pile Row Full Scale Nailed-Slab Pavement System Resting On Soft Clay Due To Concentric Loadings". Proc. 1st International Conference of Science Engineering Technology (ICoSET), Lembaga Penelitian dan Pengabdian Masyarakat (LPPM), Universitas Islam Riau, Pekanbaru, 8-9 November 2017.

Puri, A. (2015a). Perilaku Perkerasan Sistem Pelat Terpaku Pada Lempung Lunak. Disertasi, Program Doktor Teknik Sipil Fakultas Teknik Universitas Gadjah Mada, Yogyakarta.

Puri, A. (2015b). "Validasi Metode Analisis Lendutan Perkerasan Sistem Pelat Terpaku Pada Model Skala Penuh Dengan Satu Baris Tiang". Prosiding 
PIT XIX dan KOGEI X, HATTI, pp. 453-464, (ISBN 978-602-17221-3-8).

Puri, A. (2015c). "Studi Parametrik Perkerasan Sistem Pelat Terpaku Pada Tanah Dasar Lunak". Proc. 1st Annual Civil Engineering Seminar (ACES), pp. 305-313, (ISBN 978-979-792-636-6).

Puri, A., Hardiyatmo, H.C., Suhendro, B., Rifa'i, A. (2011b). "Contribution of Wall Barrier to Reduce the Deflection of Nailed-Slab System in Soft Clay". Proc. of $9^{\text {th }}$ Indonesian Geotech. Conf. and $15^{\text {th }}$ Annual Scientific Meeting (KOGEI IX \& PIT XV) HATTI, HATTI, Jakarta, 7-8 December 2011, pp. 299-306 (in Indonesian).

Puri, A., Hardiyatmo, H.C., Suhendro, B., Rifa'i, A. (2012a). "Determining Additional Modulus of Subgrade Reaction Based on Tolerable Settlement for the Nailed-slab System Resting on Soft Clay".IJCEE-IJENS, Vol. 12 No. 3 (2012) 32-40. 6 Agustus 2018. http://ijens.org/IJCEE\%20Vol\%2012\% 20Issue\%2003.html.

Puri, A., Hardiyatmo, H.C., Suhendro, B., Rifa'i, A. (2012b). "Application of the Additional Modulus of Subgrade Reaction to Predict the Deflection of Nailed-slab System Resting on Soft
Clay Due to Repetitive Loadings". Proceedings of Pertemuan Ilmiah Tahunan ke-16 (PIT) HATTI, Jakarta, 4 December, Indonesia, pp. 217-222.

Puri, A., Hardiyatmo, H.C., Suhendro, B.,Rifa'i, A. (2013). "Penerapan Metode Analisis Lendutan Pelat Terpaku Pada Model Skala Penuh dan Komprasi dengan Uji Pembebanan", Konferensi Nasional Teknik Sipil 7 (KoNTeKS7), Universitas Negeri Sebelas Maret, Surakarta, 24-26 October 2013, pp. G201-G211.

Puri, A., Hardiyatmo, H.C., Suhendro, B.,Rifa'i, A. (2014)."Behavior of Nailed-slab System on Soft Clay Due to Repetitive Loadings by Conducting Full Scale Test". Proc. $17^{\text {th }}$ Intrntl.Symp. FSTPT, University of Jember, pp. 739-750.

Puri, A., Hardiyatmo, H.C., Suhendro, B., Rifa'i, A. (2015)."Perilaku Perkerasan Sitem Pelat Terpaku Pada Tanah Dasar Lempung Lunak". Prosiding Konferensi Nasional Pascasarjana Teknik Sipil (KNPTS) 2015, Institut Teknologi Bandung, Bandung, 12 Nopember 2015, ISSN 2477-0086, pp. 7-17.

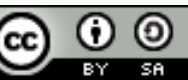

This is an open access article which means that all content is freely available without charge to the user or his/her institution. Jurnal Saintis allows the author(s) to hold the copyright without restriction. The copyright in the text of individual articles (including research articles, opinion articles, and abstracts) is the property of their respective authors distributed under the terms of the Creative Commons Attribution-ShareAlike 4.0 International License(https://creativecommons.org/licenses/by-sa/4.0/) which permits unrestricted use, distribution, and reproduction in any medium. Users are allowed to read, download, copy, distribute, search, or link to full-text articles in this journal without asking by giving appropriate credit, provide a link to the license, and indicate if changes were made. 


\section{APPENDIKS}

Tabel Data dan Besaran Perhitungan Modulus $k$ ' dan $\Delta k$

\begin{tabular}{|c|c|c|c|c|}
\hline No. & Parameter & Satuan & Nilai & Keterangan \\
\hline 1. & $\begin{array}{l}\text { Dimensi pelat beton } \\
\text { bertulang, } \\
\text { i. Panjang, }(L) \\
\text { ii. Lebar, }(B) \\
\text { iii. Tebal, }(T)\end{array}$ & $\begin{array}{l}\mathrm{m} \\
\mathrm{m} \\
\mathrm{m}\end{array}$ & $\begin{array}{l}1,2 \\
1,2 \\
0,15\end{array}$ & $\begin{array}{l}\text { Perhitungan ditinjau pada pelat } \\
\text { tiang tunggal, maka } B=\mathrm{s} \text { yaitu } 1,2 \\
\mathrm{~m}\end{array}$ \\
\hline 2. & $\begin{array}{l}\text { Dimensi tiang } \\
\text { i. } \text { Panjang, }(L p) \\
\text { ii. Diameter, }(D) \\
\text { iii. } \text { Mini pile }\end{array}$ & $\begin{array}{l}\mathrm{m} \\
\mathrm{m} \\
\mathrm{m}\end{array}$ & $\begin{array}{c}1,5 \\
0,20 \\
0,20 \times 0,20 \\
0,25 \times 0,25 \\
0,28 \times 0,28 \\
0,32 \times 0,32\end{array}$ & $\begin{array}{l}\delta_{a}=\delta_{s} \text { untuk dia. } 20 \mathrm{~cm} \\
\text { Lendutan izin maksimum untuk } \\
\text { minipile }\left(\delta_{a}=5 \mathrm{~mm}\right) .\end{array}$ \\
\hline 3. & Kohesi undrained $\left(c_{\mathrm{u}}\right)$ & $\mathrm{kN} / \mathrm{m}^{2}$ & 20,14 & - \\
\hline 4. & Uji lapangan, $k_{v}$ & $\mathrm{kN} / \mathrm{m}^{3}$ & 15.000 & - \\
\hline 5. & Modulus reaksi subgrade $(k)$ & $\mathrm{kN} / \mathrm{m}^{3}$ & 4.500 & $\begin{array}{l}\text { Koreksi } k_{v} \text { dengan metode Das } \\
\text { (2011) yang kemudian dikalikan } B\end{array}$ \\
\hline \multirow[t]{2}{*}{6.} & $\begin{array}{l}\text { Tahanan satuan ultimit, } \\
\text { i. Tahanan gesek satuan } \\
\text { ultimit, }\left(f_{s}\right)\end{array}$ & $\mathrm{kN} / \mathrm{m}^{2}$ & 20,14 & $\begin{array}{l}\text { Dari kohesi }(c) \text { berdasarkan kurva } \\
\text { Tomlinson pada Grafik Mc } \\
\text { Clelland (1974) diperoleh faktor } \\
\text { adhesi }\left(a_{d}\right)=1,0 \text {, maka } f_{s}=c_{\mathrm{u}} a_{d}\end{array}$ \\
\hline & $\begin{array}{l}\text { ii. Tahanan ujung satuan } \\
\text { ultimit, }\left(f_{b}\right)\end{array}$ & $\mathrm{kN} / \mathrm{m}^{2}$ & 181,26 & $\begin{array}{l}\text { Pada tanah lunak menurut } \\
\text { Skempton }(1956) \text { faktor kapasitas } \\
\text { dukung }\left(N_{c}\right)=9 \text {, maka } f_{b}=c_{\mathrm{u}} N_{c}\end{array}$ \\
\hline 7. & 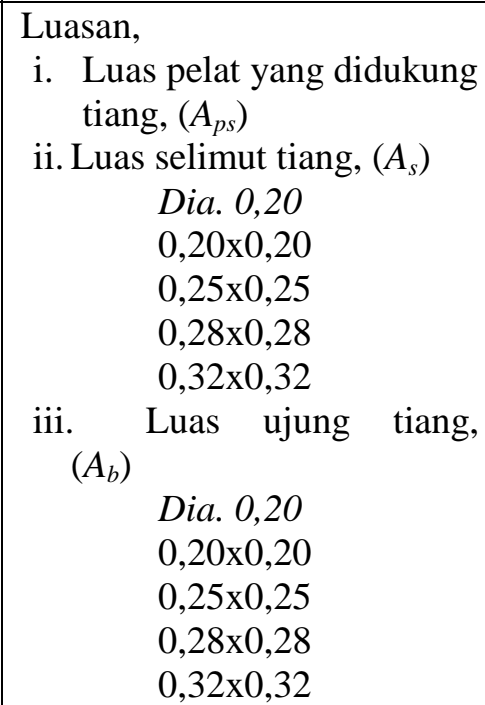 & $\begin{array}{l}\mathrm{m}^{2} \\
\mathrm{~m}^{2}\end{array}$ & $\begin{array}{c}1,44 \\
\\
0,942 \\
1,20 \\
1,50 \\
1,68 \\
1,92 \\
\\
0,0314 \\
0,040 \\
0,0625 \\
0,0784 \\
0,1024\end{array}$ & \\
\hline
\end{tabular}

Sumber : Puri (2017) 
J.Saintis, Vol. 18. No. 2, 2018: 13 - 23

Tabel Nilai $\Delta k$ dan $k^{\prime}$

\begin{tabular}{|c|c|c|c|c|c|c|}
\hline \multirow{2}{*}{$\begin{array}{c}\text { Dimensi } \\
\text { Tiang }(\mathbf{c m})\end{array}$} & \multirow{2}{*}{$\begin{array}{c}\text { Beban } \\
(\mathbf{k N})\end{array}$} & \multirow{2}{*}{$\begin{array}{l}\text { Modulus } \\
\text { Reaksi } \\
\text { Subgrade } \\
\left(\mathbf{k N} / \mathbf{m}^{3}\right)\end{array}$} & \multicolumn{4}{|c|}{$S F$} \\
\hline & & & 1,0 & 2,0 & 2,5 & 3,0 \\
\hline \multirow{5}{*}{ dia. 20} & \multirow{2}{*}{5} & $\Delta k$ & 54441,80 & 27220,90 & 21776,72 & 18147,27 \\
\hline & & $k^{\prime}$ & 58941,80 & 31720,90 & 26276,72 & 22647,27 \\
\hline & \multirow{2}{*}{10} & $\Delta k$ & 27620,37 & 13810,19 & 11048,15 & 9206,79 \\
\hline & & $k^{\prime}$ & 32120,37 & 18310,19 & 15548,15 & 13706,79 \\
\hline & 20 & $\Delta k$ & 13402,76 & 6701,38 & 5361,11 & 4467,59 \\
\hline
\end{tabular}

Tabel Lanjutan

\begin{tabular}{|c|c|c|c|c|c|c|}
\hline \multirow{2}{*}{$\begin{array}{c}\text { Dimensi } \\
\text { Tiang }(\mathbf{c m})\end{array}$} & \multirow{2}{*}{$\begin{array}{c}\text { Beban } \\
(\mathbf{k N})\end{array}$} & \multirow{2}{*}{$\begin{array}{c}\text { Modulus } \\
\text { Reaksi } \\
\text { Subgrade } \\
\left(\mathrm{kN} / \mathrm{m}^{3}\right)\end{array}$} & \multicolumn{4}{|c|}{$S F$} \\
\hline & & & 1,0 & 2,0 & 2,5 & 3,0 \\
\hline & & $k^{\prime}$ & 17902,76 & 11201,38 & 9861,11 & 8967,59 \\
\hline & \multirow{2}{*}{40} & $\Delta k$ & 4470,62 & 2235,31 & 1788,25 & 1490,21 \\
\hline & & $k^{\prime}$ & 8970,62 & 6735,31 & 6288,25 & 5990,21 \\
\hline & \multirow{2}{*}{60} & $\Delta k$ & 2248,28 & 1124,14 & 899,31 & 749,43 \\
\hline & & $k^{\prime}$ & 6748,28 & 5624,14 & 5399,31 & 5249,43 \\
\hline \multirow{2}{*}{$20 \times 20$} & \multirow{8}{*}{$\begin{array}{c}5,10, \\
20,40, \\
60\end{array}$} & $\Delta k$ & 3356,67 & 1678,33 & 1342,67 & 1118,89 \\
\hline & & $k^{\prime}$ & 7856,67 & 6178,33 & 5842,67 & 5618,89 \\
\hline \multirow{2}{*}{$25 \times 25$} & & $\Delta k$ & 4195,83 & 2097,92 & 1678,33 & 1398,61 \\
\hline & & $k^{\prime}$ & 8695,83 & 6597,92 & 6178,33 & 5898,61 \\
\hline \multirow{2}{*}{$28 \times 28$} & & $\Delta k$ & 4699,33 & 2349,67 & 1879,73 & 1566,44 \\
\hline & & $k^{\prime}$ & 9199,33 & 6849,67 & 6379,73 & 6066,44 \\
\hline \multirow{2}{*}{$32 \times 32$} & & $\Delta k$ & 5370,67 & 2685,33 & 2148,27 & 1790,22 \\
\hline & & $k^{\prime}$ & 9870,67 & 7185,33 & 6648,27 & 6290,22 \\
\hline
\end{tabular}

